\title{
Gebelikte Teratojen Enfeksiyonlara Güncel Yaklaşım
}

A Current Approach to Teratogenic Infections in Pregnancy

\section{Gülseren DAĞLAR ${ }^{1}$, Dilek BİLGİÇ ${ }^{2}$}

1. Cumhuriyet Üniversitesi Sağllk Bilimleri Fakültesi, Ebelik Bölümü, Sivas

2. Dokuz Eylül Üniversitesi Hemşirelik Fakültesi, İzmir

\section{$\ddot{O} Z E T$}

Gebelikte geçirilen enfeksiyonlar gebelik üzerine olumsuz etki oluşturmakla birlikte intrauterin enfeksiyonlar perinatal mortalite ve morbiditenin en önemli nedenleri arasında yer almaktadır. Teratojen enfeksiyonlar gebelik döneminde geçirildiğinde fetüste benzer klinik tablo oluşturduğundan birlikte değerlendirilmektedir. Bu enfeksiyonlar ayrica önemli kllan bir durum da gebede asemptomatik seyrettiği halde fetüste ileri düzeylerde sekellere neden olmasıdır. Gebeliğinde enfeksiyon yaşayan kadınların ve fetüslerin ise enfeksiyonun tanılanması, gebeliğin yönetimi, anneden fetüse bulaşın önlenmesinde hem doğumun hem de sonraki bakımın güvenli biçimde gerçekleştirilebilmesi için bakımın kaliteli olması, gereksiz uygulamalardan kaçınılması, rutin uygulamada olmayan fakat yararı kanıtlanmış uygulamaların işlevselliğinin arttırılması, yarar sağlamayan uygulamaların kullanımından kaçınılması ancak kanıt temelli güncel yaklaşımlarla sağlanabilir. Bu derlemede gebelikte enfeksiyon hastalıklarında uygulanan girişimler (aşılama, serolojik tarama ve tanı ve tedavi) literatürde yer alan randomize çalışmalar, meta-analiz ve sistematik derleme sonuçları ile tartışılacaktır.

Anahtar Kelimeler: teratojen enfeksiyonlar, gebelik, güncel yaklaşım

\section{SUMMARY}

Infections experienced in pregnancy have negative effects on pregnancy and intrauterine infections fall within the most important reasons of perinatal mortality and morbidity. Teratogenic infections create a clinically similar picture, they should be assessed together. Another point making the said infections important is the fact that they cause advanced sequelae in fetus even though they progress asymptomatically in pregnant woman. It may be possible only with proof-based approaches to diagnose the infection in the women and fetuses who experienced infection during their youths, to manage pregnancy, to provide quality healthcare in order to carry out both delivery and postnatal care safely in preventing the transmission of infection from mother to child, to avoid unnecessary applications, to increase the functionality of the applications which are non-routine but proven to be useful, to avoid using unpractical applications. Healthcare professionals should take proof-based approaches as a guide in providing healthcare in order to reach the said targets and integrate them into clinical practice. The purpose in this compilation is to discuss the operations in case of infectious diseases in pregnancy (vaccination, serological screening and diagnosis tests, prenatal diagnosis tests, treatment and newborn breastfeeding) with the results of meta-analysis and systematic compilation of randomized studies in the literature.

Keywords: teratogen infections, pregnancy, current approach

İletişim

Sorumlu Yazar: Yard. Doç. Dilek BíLGiç

Adres: Dokuz Eylül Üniversitesi Hemşirelik Fakültesi, İzmir

Tel: +90 (542) 2561804

E-Posta: dilekbilgic44@gmail.com

Makale Geliş: 17.03.2017

Makale Kabul: 23.05.2017

DOI: http://dx.doi.org/10.16948/zktipb.298708 


\section{GİRIŞ}

Gebelik, doğum ve doğum sonu dönem fizyolojik olaylar olduğu halde sağlık hizmeti gereksiniminin arttığ 1 dönemlerdir. Bu nedenle ana çocuk sağlığının temelini oluşturan bu dönemde hem anne hem de fetüs özel bir bakıma gereksinim duyar. Gebeye ve fetüse verilecek olan bu bakımda gebelikte geçirilen enfeksiyonlar ayrı bir öneme sahiptir. Intrauterin dönemde fetüs enfeksiyonlara çok duyarlıdır; özellikle organogenez döneminde geçirilen enfeksiyonlar teratojen etki gösterebilir [1]. Teratojenik etkiye sahip oldukları bilinen enfeksiyon ajanları rubella, sitomegalovirus (CMV), varisella, toksoplazma, sifiliz ve diğerleridir. Teratojenik enfeksiyonun gebeyi ve fetüsü etkilemesi enfeksiyonun geçirilme zamanına, etkilenen sisteme ve enfeksiyonun şiddetine göre değişmektedir [2].

Dolayısıyla sağlık çalışanlarının amacı; gebe kadınlarda enfeksiyon gelişmesini önlemek, enfeksiyon geliştiğinde erken tanı ve tedavisini sağlayarak anne ve fetüs sağlığını korumak ve yükseltmek olmalıdır. Bu amaçlara ulaşabilmek için hizmeti sunarken sağlık çalıșanları kanıta dayalı güncel bilgi ve uygulamaları rehber almalı, klinik ile entegre etmelidir. Bu derlemede amaç gebelikte enfeksiyon hastalıklarında uygulanan girişimleri (gebelik yönetiminde danışmanlık, korunma, aşılama, serolojik tarama ve tanı testleri, tedavi, gebeliğin yönetimi ve doğum şekli) literatürde yer alan randomize kontrollü çalıșmalar (RKÇ), meta-analiz ve sistematik derleme sonuçları doğrultusunda tartışarak bu konudaki güncel yaklaşımlara yer vermektir.

\section{Teratojen Enfeksiyonların Görülme Sıklığı}

Teratojen enfeksiyonlar için uygulanan girişimlerde öncelikle o bölgeye ait seropozitiflik oranlarının bilinmesi gerekir. Ülkemizde ilk trimesterdeki 2900 gebede toksoplazma, rubella, cytomegalovirus (CMV) seroprevelanslarını belirlemek amacıyla yapılan bir çalıșmada seropozitiflik yüzdeleri Toksoplazma IgG $(\% 31,2)$, IgM (\%0.9); Rubella IgG (\%95,7), $\operatorname{IgM}(\% 0.15)$, CMV $\operatorname{IgG}(\% 99,2), \operatorname{IgM}(\% 0,7)$ olarak saptanmıştır [3]. Doğurganlık çağındaki kadınların \%10-15'i rubella infeksiyonuna duyarlıdır [4]. Yabancı çalışmalarda doğurganlık çağındaki kadınlarda toksoplazma seropozitifliği \%11 ile \%75,2 gibi değisșen oranlarda [5] ülkemizde de farklı şehirlerde yapılan çalışmalarda da diğer ülkelerde olduğu gibi \%18.3 ile 68.9 arasında değişen oranlarda bildirilmiştir [6]. Her yıl çoğunluğu gelişmekte olan ülkelerde olmak üzere yaklaşık 2 milyon gebe önlenebilir sifiliz enfeksiyonu yaşamakta [7], en az yarım milyon bebek konjenital sfiliz ile doğmaktadır [8]. Primer maternal CMV enfeksiyonu, her 300 gebeden birinde ortaya çıkmakta ve her 1000 yenidoğandan birini etkileyecek şekilde olguların \%40'ında fetal enfeksiyonla sonuçlanmaktadır [9]. Gebelerin yaklaşık \%20-30'unda Herpes Simpleks Virus 2 (HSV 2) IgG pozitiftir. Gebelikteki HSV ataklarının \%90'ından fazlası ya rekürren ya da primer olmayan ilk HSV enfeksiyonudur. Gebelerin yaklaşık \%90'1 varisellaya bağışık olduğundan primer maternal varisella zoster virus (VZV) enfeksiyonu nadirdir [8]. 1947 den 2013 yilına kadar bildirilen 130 konjenital varisella zoster vakasının incelendiği bir sistematik derlemede gebeliğin başlangıcında VZV enfekte olan kadınlarda konjenital varisella sendromu insidansı $\% 0,59$, gebeliğin ilk 20 haftası içerisinde enfekte olan kadınlarda ise $\% 0,84$ olarak belirlenmiştir [10]. Doğurgan çağdaki kadınların \%40'1 parvovirus B19 infeksiyonuna duyarlı olup y1llık serokonversiyon oranı epidemi görülmeyen yıllarda \%1-2, epidemiler sirasinda ise \%10-15 oranlarına kadar değişebilmektedir [11].

\section{Sifiliz}

Son yıllarda antenatal sifiliz tarama programlarının yaygınlığına rağmen sifiliz gelişmekte olan ülkelerde önemli bir halk sağlı̆̆ sorunu olmaya devam etmektedir [7]. Endemik sfiliz cinsel ilişki dışında aktif lezyon ile yakın temasla bulaşabilir ve kötü hijyen koşullarında yaşayan topluluklarda daha siktır. Maternal risk faktörleri arasında çok sayıda cinsel partner, korunmasız cinsel ilişki ve diğer cinsel yolla bulaşan hastalıklar sayılabilir [8].

\section{Cytomegalovirus (CMV)}

CMV viral intrauterin enfeksiyonların en sık nedenidir [8, 12, 13]. Risk faktörleri düşük sosyoekonomik düzey [14], enfekte kişilerle temas, çok eşlilik, çok yaşlı veya çok genç olmak, multiparite ve kan transfüzyonudur. CMV cinsel temasla bulaşabildiği gibi, gebelik sırasında, CMV bulaşması görülen olguların çogunda evde veya mesleki nedenlerle enfekte çocuklarla temas ile olur $[1,8,13]$. CMV genellikle asemptomatiktir veya hafif semptomlar nedeniyle tanı konulamadan seyreder [8].

\section{Toksoplazmozis}

Toksoplazmada hemen her zaman maternal semptom olmamakla birlikte nadiren grip benzeri ateş, yorgunluk, döküntü ve lenfadenopati olabilir. Gebelikte primer maternal toksoplazma gondi enfeksiyonu fetal enfeksiyona neden olabilir $[8,15]$. 


\section{Rubella/Kızamıkçık}

Rubella enfeksiyonu, erişkinde ve çocukluk döneminde kızamık benzeri döküntülü ve hafif bir klinik tablo oluşturan fetüste ise ciddi malformasyonlara yol açan önemli bir enfeksiyondur [16]. Teratojenik viral enfeksiyonlardan en iyi bilinendir. Gebeliğin ilk trimesterinde annenin kızamıkçık geçirmesi fetüste önemli ölçüde teratojenik etkiye neden olur [1].

\section{Herpes Simpleks}

Gebelerde yeni edinilen HSV enfeksiyonlar1 \%70 oranında asemptomatik seyretmektedir. HSV $1 \% 90$ oranında oral, $\% 10$ oranında genital enfeksiyonlara neden olurken HSV 2 $\% 10$ oranında oral, $\% 90$ oranında genital enfeksiyonlara neden olmaktadır [8].

\section{Parvovirus}

Enfeksiyon kış ve ilkbaharda daha sık görülür. Enfeksiyon riski küçük enfekte çocuklar ile temas düzeyi ile ilişkilidir $[8,17]$. En yüksek enfeksiyon oranları öğretmenler, bakıcılar, kreș veya okul çağındaki çocuklarla aynı evde bulunan kadınlarda görülmektedir [8, 11]. Erişkinlerde enfeksiyonların en az yarısı asemptomatiktir [8].

\section{Varisella/ Suçiçeği}

Sık görülen bir çocukluk çağı hastalığı olan varisella enfeksiyonu çocuklarda hafif seyrederken erişkinlerde şiddetli hastalık tablosu oluşturur. Gebelerin yaklaşık \%90'1 varisellaya bağ 1 șik olduğundan primer maternal enfeksiyon nadir görülmektedir $[4,8,15]$. Maternal varisella enfeksiyonu enfekte bireylerle özellikle de immünize olmayan çocuklarla temas sonucu oluşur $[8,15]$. Virus çok bulaşıcıdır, damlacık yoluyla ve vezikül sıvisı ile direkt temas yoluyla bulaşır [8].

\section{Teratojen Enfeksiyonların Yönetimine Ka- nıt Temelli Güncel Yaklaşım}

$\mathrm{Bu}$ bölümde teratojen enfeksiyonların yönetimi kapsamında danışmanlık, korunma, tarama, anneden bebeğe geçiş, gebeliğin yönetiminde erken tanı, tedavi ve doğum şekline yer verilmişstir.

\section{Gebelik yönetiminde danışmanlık}

Enfeksiyonlardan korunmada ideal olan, gebelik planlayan kadın ve eşinin prekonsepsiyonel bakım alarak gebeliğe karar vermesi olduğundan prekonsepsiyonel bakımda enfek- siyonlara yönelik danışmanlık önemlidir. Danışmanlıkta korunma, hastalığın doğal seyri, vertikal geçiş, sekeller, prognoz ve tedavi seçenekleri yer almalıdır [8]. Gebelik öncesi yapılacak testler teratojen enfeksiyonlara yönelik kadının immünitesini belirleyecek şekilde rutin antenatal tarama testlerini içermelidir. Danışmanlıkta, çiftlere rastgele/korunmasızcinselilişki ve damar içi uyuşturucu kullanımı ile enfeksiyon riski arasındaki ilişkiler de anlatılmalıdır [4]. CMV'nin insidansının ve konjenital CMV enfeksiyonunun neden olduğu mortalitenin yüksek olmasindan dolayı konjenital CMV enfeksiyonunun önlenmesi önemlidir [14]. Gebelikte CMV geçiş riskini azaltmada gebelere mutlaka danışmanlık yapılması önerilmektedir [13].

Toksoplazmadan korunmada önemli olan duyarlı anne adaylarının eğitilmeleridir. Özellikle "çiğ köfte" gibi çiğ etle yapılan yöresel yemekleri sıkça tüketen, hijyen koşulları kötü, evde kedi bulunduran kadinlara toksoplazmozisin bulaş yolları ve bu parazitle enfeksiyondan korunma konusunda eğitim verilmelidir $[6$, $18,19]$. Yapılan bir RKÇ da prenatal eğitimin gebelerin bilgisini geliştirmede önemli bir etkiye sahip olduğu ancak davranış değişikliğinde etkisi olmadığı saptanmıştır [20]. Di Mario ve arkadaşları tarafından yapılan Cochrane sistematik incelemesinde (2015) de, konjenital toksoplazmayı önlemede prenatal eğitimin etkisini destekleyen veriler eksik olarak değerlendirilmiş ve bu konuda daha fazla RKÇ ihtiyaç olduğu belirtilmiştir. Prenatal eğitimin konjenital toksoplazma ve gebelikte serokonversiyon oranı üzerine etkisini belirleyen RKÇ bulunmadığ 1 bildirilmiştir [21].

Primer maternal HSV, Parvovirus, VZV enfeksiyonunda da danışmanlık önemlidir. Danışmanlıkta korunma, hastalığın doğal seyri, vertikal geçiş, sekeller, prognoz ve tedavi seçenekleri yer almalıdır [8].

\section{Korunma}

Sfilizden korunma amaciyla erken tanı ve tedavi, eş tedavisi ve yüksek riskli toplumlarda asemptomatik olguların belirlenmesi için tarama yapılmalıdır [8].

CMV enfeksiyonundan korunmada temizlik çok önemlidir. Korunmaya yönelik bir özen gösterilmemesine kıyasla, özellikle gün içerisinde küçük çocuklar ile temasta bulunan seronegatif kadınlarda korunma önlemleri (çocuklarla yakın temastan kaçınma, sık el yıkama, eldiven kullanımı) ile gebelik boyunca CMV geçişini önlemede müdahale son derece etkili olabilir [13]. 
Konjenital toksoplazmoziste en iyi tedavi korunmadır. Toksoplazmada korunmaya yönelik uygulamaların hastalığın insidansını azalttığ gösterilmiştir ve bu uygulamalar diğer tüm girişimler arasında en önemli yere sahiptir [8]. Korunmadaki amaç; seronagatif gebenin, gebeliği süresince akut toksoplazma enfeksiyonu geçirmesini önlemektir $[1,8]$.

Maternal HSV enfeksiyonundan korunma enfekte bireylerle cinsel ilişkiden kaçınmayla olur. Erken gebeliklerde çiftlerin yaklaşık \%1525 'inde HSV çiftlerden birinde mevcut olup bu durumda kadının partnerinden primer enfeksiyon bulaşma riski bulunmaktadır. Enfekte erkek eşten korunmada kondom kullanımı önemlidir. Fetal/neonatal enfeksiyondan korunmada primer enfeksiyon durumunda vajinal doğumdan kaçınılmalı sezaryenle doğum gerçekleștirilmelidir $[8,18]$.

Parvovirusde enfekte çocuklarla temastan kaçınmak ya da genel olarak çocuklardan uzak durmak en iyi korunmadir ancak bu her zaman sağlanabilecek bir durum değildir [8]. Varisella enfeksiyonundan korunmada doğurgan çağdaki kadınların, varisellaya karşı bağışıklığı saptanmalı ve bağıșık olmayanlara așı önerilmelidir $[18,22]$. VZV seronegatif gebeler varisella olan kişilerle temastan kaçınmalıdır $[8,18]$.

\section{Aşılama}

Enfeksiyon etkeninin fetüse geçiş riski olduğundan gebelikte canlı aşılar kontrendikedir. Bu așllar gebelikte veya gebelik öncesi son dört haftada rutin olarak kullanılmamalıdır. Ancak gebelik öncesi son dört haftada veya gebelikte canlı aşıya maruz kalma gebeliğin sonlandırılması için endikasyon değildir [8].

Canlı CMV aşısı vardır, fakat reaktive edilebilir ve güvenlik konuları henüz çözülmemiştir [8]. Bununla birlikte CMV ye karşın hem aktif hem de pasif bağıșıklamanın maliyet etkin olduğunu gösteren çalışmalarla birlikte ulusal tarama ve pasif bağışıklamanın yapılmasının da maliyet etkili olduğunu bildiren çalışmalar bulunmaktadır [13].

Rubelladan korunmada aşılanma önemlidir. Ancak rubella aşısı canlı olduğundan teratojenik etkiye sahiptir ve gebelikte yapılmaz [1, 15]. 1969'dan itibaren rubella așilamasıyla konjenital rubella sendromunun siklığ 1 azalmış [23], 2008 y1lından itibaren rubella aşıs1 127 ülkenin ulusal aşı programına dahil edilmiştir. Ülkemizde de 2006 y1lında rubella aşısı rutin uygulama programındadır ancak ülkemizde sadece rubellaya karşı aşı bulunmadığından
Kızamık-Kızamıkçık-Kabakulak (KKK) karma aşısı yapılmaktadır [16]. Riley (2010) çalışmasında erken gebelik sırasında yanlışlıkla aşılanan gebelerin hiçbirinde konjenital rubella sendromu bildirilmediğini belirtmektedir. [24].

Parvovirusde aşı ile aktif immünizasyon mevcut değildir. İntravenözimmünglobulin (IVIG) profilaksisi immün yetmezliği olan olgularda belirlenmiş temaslar için düşünülebilir [8].

Doğurganlık çağındaki enfeksiyona duyarlı kadınlara varisella aşısının önerilmesi, konjenital ve neonatal varisella insidansinı azaltmaktadır [22]. Canlı-zayıflatılmış varisella aşısının erişkinlerde varisellayı önlemede güvenli olduğu gösterilmiştir. Varisella canlı aşı olduğundan gebelikte yapılmasi kontraendikedir $[8,18,22$, 25]. Rutin olarak önerilmemekle birlikte bağ1şıklığ1 olmayan (2 doz varisella aşısı yapılmamiş, kan testleri ile immunitesi gösterilmemiş, varisella ya da herpes zoster-zona geçirdiği tanımlanamayan) anne adaylarına varisella aşısı gebe kalmadan en az 1 ay önce yapilabilir [8, 25]. KKK aşısında olduğu gibi varisella aşısı yapılan kadına bir ay içinde gebe kalmaması belirtilmelidir. Eğer 4 hafta içinde gebe kalırsa veya gebeyken aşı yaptırmıșsa teorideki endișeler konusunda hasta bilgilendirilmelidir. Fakat bu bir terminasyon endikasyonu değildir aş1sının gebelikte yapılması kontraendikedir [8]. Varisella ile temastan sonra duyarlı gebeler için immünprofilaksi mevcuttur [4]. Varisella zoster immunoglobulin (VZIG) virüse maruz kalan ve virüsle enfekte olma şüphesi olan kadınlarda enfeksiyonun gebelikte geçirilmesi halinde ağır ve komplikasyonlu seyretme ihtimali yüksek olduğundan mutlaka önerilmelidir $[15,18,19]$.

\section{Tarama}

Gebelerde görülen ve fetal anomalilere yol açan intrauterin enfeksiyonlar için prenatal serolojik tarama yapılması araştırmacılar arasında tartışmalı bir konudur. Tarama, tüm gebe kadınlarda uygulanmalıdır. Risk faktörlerine göre seçici tarama yeterli olmayabilir. İlgili enfeksiyon için risk faktörlerinin belirlenmesi uzun zaman aldığı gibi riskli gebelerin tümü de tanımlanamamaktadır. Tavsiyelerin çoğu enfeksiyonların epidemiyolojisindeki değișimlere, tarama testlerinin ve girișimlerin varlığ 1 ve maliyetine bağlı olarak popülasyonlar arasında ve zaman içinde değişebilmektedir [4].

Sifiliz görülen gebelerin çoğu asemptomatik olduğundan ancak serolojik tarama ile saptanabilir [8]. Sifilizden korunma amaciyla tüm gebelerde tarama yapılmasi ve reaktif olanların tedavisi ile gebelikle oluşan enfeksiyonlara 
bağlı komplikasyonlar azaltılabilir [8]. U.S. Preventive Services Task Force 2009 sonuç bildirgesinde de tüm gebelere sifiliz enfeksiyonu açısından tarama yapılması önerilmektedir [26]. Son yıllarda sifiliz testi programları ve tarama teknolojisindeki önemli ilerlemelere rağmen, başarılı önleme ve sifiliz tedavisi sınırlı olmuştur. Testlerin teknik ve lojistik zorlukları, doğum öncesi bakım eksikliği ve düşük kaliteli hizmet büyük ölçüde enfekte kadınların belirlenmesi ve tedavide gecikmelere neden olan faktörlerdir [7].

CMV nin serolojik tanılamasının altın standart maternal serokonversiyonda CMV IgG antikorlarının belirlenmesidir [13]. Randomize olmayan ancak iyi planlanmış kontrollü çalıșma sonuçlarına göre gebelikte primer maternal CMV enfeksiyonunun tanılaması öncelikle seronegatif olan gebelerde spesifik IgG nin görülmesiyle veya düşük IgG varlığında spesifik IgM saptanmasına temellenmelidir [12]. Gelişmekte olan ülkelerde çok erken yaşlarda hastalık geçirilebildiğinden, CMV saptanması durumunda etkin bir tedavisinin olmamasından, etkilenmemiş fetüslerde gereksiz terminasyon yapılmasından ve ailenin yaşayacağı anksiyeteden dolayı gebelerde rutin CMV taraması yapılması tartıșmalıdır [27]. Gebelikte CMV taraması seronegatif kadınlarda dahi pek çok ülkede rutin olarak önerilmemektedir [4, 12]. Ancak gebelikte grip benzeri hastalık geçiren gebelerde veya utrasonongrafide CMV enfeksiyonunu andiran bulgular belirlendiğinde serolojik testlerin yapılması düşünülebilir. Bazı ülkelerde gebelerin tümü veya yarısından fazlası gebelik sirasında CMV serokonversiyon açısından rutin tarama yapılmaktadır. Amerika'da gebelerde rutin tarama olarak rubella, sifiliz, hepatit ve HIV taramasiyla beraber CMV eklenerek uygulanabileceği belirtilmektedir. İsrail ve sekiz Avrupa ülkesinde (Fransa, Belçika, İspanya, İtalya, Almanya, Avusturya, Portekiz ve Hollanda) gebelerin çoğunluğu rutin olarak serolojik açıdan CMV ye karşı taranmaktadır [13]. CMV tanılanmasında ideal olan, çocuk bakıcısı gibi CMV enfeksiyonu riski taşıdığı düşünülen kadınlarda, gebe kalmadan önce IgG testi yapılmasıdır [4].

Gebelerde rutin toksoplazma tarama programları Fransa ve Avusturya gibi bazı Avrupa ülkelerinde kullanılmakla birlikte ABD ve İngiltere'de prenatal veya neonatal tarama tartışmalı olup bazı tıp çevrelerince önerilmemektedir [8, 18]. Ülkemizde de sağlıkl gebelerde seropozitifliğin yüksek oranda bulunması [5] ve doğurgan çağdaki kadınlarda yüksek toksoplazma seronegatifliğinin saptanması [6] gebelik öncesi ve gebelik sirasinda toksoplazma serolojisinin taranmasının önemli olduğunu göstermekle birlikte tarama gerekli olmayabilir kanısını da oluşturmaktadır. Bu taramaların maliyet-etkinlik açısından risk grubunda olan kadınlarda yapılması daha uygun olabilir.

Doğurgan yaştaki kadınlarda Rubella spesifik IgG ve IgM antikor taramalarındaki asıl amaç seronegatifleri aşılamak ve konjenital rubella sendromunu önlemektir. Ülkemizde doğurgan yaştaki kadınlarda tespit edilen $\% 95,8$ gibi [6] yüksek rubella seropozitiflik oranı, taramanın rutin olarak mutlak gerekli olmadığını düşündürmektedir. Ancak seronegatif olan kadınların gebe kalmayı istemesi durumunda aşılanması konjenital enfeksiyonların önlenmesi açısından önemli olmaktadır [6].

HSV' de maternal enfeksiyonun engellenmesi en önemli yönetim stratejisidir. HSV enfeksiyonuna yönelik yeni enfeksiyon riski olan kadınları belirlemek amaciyla tarama yapılmasının termde enfeksiyon insidansını etkili bir şekilde azaltacağına dair kanıt bulunmadığından gebelere tarama yapılması önerilmemektedir [8]. Bütün kadınlar genital herpesin olası her belirtisi için doğum eyleminin başlangıcında vajinal değerlendirme sırasında muayene edilmeli, herhangi bir sorun varlığında sağlık çalışanları uyarılmalıdır [18].

Tarama yapılan kadınlarda Parvovirus B19 fetal hidrops gelişme riski 1/5000 olduğundan parvovirus enfeksiyonuna yönelik tarama önerilmemektedir. Özellikle epidemiler sırasında küçük çocuklara bakan gebelerde tarama gerekebilir. Bazı ülkelerde parvovirus IgG testi maternal ve fetal infeksiyon riski ve hasarın düşük olmasından, aşı ve tedavisinin bulunmamasından dolayı rutin tarama testlerinden çıkarılmıştır [4]. Tüm gebelerin varisella için rutin serolojik taraması önerilmemektedir. Gebe kadınların tümüne ilk prenatal kontrolde varisella geçirip geçirmediği sorulmalıdır [8].

\section{Anneden bebeğe geçişin önlenmesi}

Gebe kadında vertikal bulaşan bir enfeksiyon kanıtlanmışsa veya enfeksiyonun olmadiğ1 ekarte edilemiyorsa, enfeksiyonun tipine ve gebeliğin dönemine bağlı olarak fetüste risk oluşturmaktadır [4]. Maternal ve fetal enfeksiyon için düşünülen girişimler laboratuarda doğrulanmış sonuçlara dayalı olmalı ve enfeksiyon tipine göre bilinen fetal hasar riskleri göz önünde bulundurulmalıdır [13].

Fetal sifiliz spiroketin transplasental geçişi sonucu fetal dolaşıma geçmesi ve enfeksiyona neden olmasiyla meydana gelir. Konjenital sfiliz için tek başına en büyük risk faktörü 
maternal hastalığın evresidir [8, 15]. Erken evre hastalıkta fetüs ve yenidoğanların \%83'ü etkilenmekte [8] özellikle gebeliğin ilk ayında anne enfekte ise enfeksiyon \%100 fetüse geçmekte ve bebek konjenital sifilizli doğmaktadır $[1,18]$. Tedavi edilmeyen veya tedavisi yetersiz olan sifilizli gebelerin yaklaşık \%69'unda enfeksiyon fetüse geçebilir ve fetüste spontan abortus, ölü doğum, non immün hidrops fetalis, erken doğum veya perinatal morbidite ve mortalite gibi ciddi sonuçlara yol açabilir [28].

CMV enfeksiyonu, primer enfeksiyon görülen gebelerin yaklaşı1 \%30-40'ında fetüse geçer $[12,12,29]$. Fetüse geçiş oranı gebelik haftasinın ilerlemesiyle birlikte artar ve üçüncü trimesterde en fazla orana ulaşır $[8,13,30]$ fakat hastalığın ciddiyeti gebelik haftasıyla ters orantılıdır ve fetüs en fazla ilk trimesterde etkilenir $[1,8,12,14,19]$. CMV konjenital sensorinöral işitme kaybının $[12,14,15]$ ve mental retardasyonun $[12,15,19]$ en sik nedenidir. Yapılan bir Cochrane sistematik (2011) çalışmada gebelikte enfekte anneden fetüse CMV bulaşmasını ve konjenital enfekte bebekte istenmeyen sonuçlar1 önlemek için doğum öncesi girişimleri inceleyen RKÇ bulunamamıştır. Gebelik sırasında anneden fetüse CMV geçişini önlemeyi amaçlayan girişimlerin etkinliğini değerlendirmek için enfeksiyona maruz kalan yenidoğanların izlendiği maliyet etkili analizleri içeren daha fazla araştırmaya gereksinim olduğu belirtilmiştir [14].

Toksoplazmada fetal enfeksiyon maternal enfeksiyonun gerçekleştiği gebelik haftasına bağlıdır. Maternal enfeksiyon ilk trimesterde gerçekleşirse fetal/neonatal hastalık daha şiddetlidir. Anneden fetüse geçiş doğrudan doğruya gebelik haftasıyla orantılidır $[5,8,15,18]$. Genel olarak primer enfeksiyon görülen kadınların fetüslerinin yaklaşık \%7'si etkilenmekte$\operatorname{dir}[8]$.

Rubella virusu transplasental yolla fetüse geçer $[1,15]$ ve bebek konjenital rubella sendromu ile doğar [1]. Fetal enfeksiyon ve fetal hasar riski, gebeliğin ilk üç ayında \%80 olup ilk üç aydan sonra fetal hasar riski giderek azalır ve ikinci üç ayda $\% 25$ 'e düşer [31].

Anneden bebeğe HSV geçişi genellikle doğum sirasinda enfekte genital sekresyonlarla temas sonucu oluşur $[8,15,18]$. İlk primer enfeksiyon atağ1 sırasında vajinal doğum sonucu neonatal HSV enfeksiyonu insidans1 \%40-50 dir [8, 18]. Yenidoğan herpes simpleks insidans1 ortalama 10.000 doğumda 2'dir. Annenin gebelik esnasında geçirdiği ilk enfeksiyonun, tekrarlayan bir enfeksiyona göre fetüsü enfekte etme ola- sılığ1 yüz kattan daha fazladır [19]. Yenidoğanın gözleri, nazofarinksi ve derisindeki yaralar virus için giriş kapılarıdır. Transplasental yolla geçiş nadirdir [8].

Parvovirusün fetal anomaliye yol açtığ 1 görülmemiştir. Ancak erken gebelik döneminde fetal anemiye yol açabilir [18, 19]. Gebeliğin 20. haftasından önce geçirilen rahim içi bir enfeksiyon olguların \%10'unda fetal ölüme neden olur; gebeliğin daha geç dönemlerinde risk yaklaş1k \%1'e düşer. 24. gebelik haftasında veya sonraki haftalarda ki enfeksiyon genellikle fetüste önemli sorunlara yol açmaz [19]. Akut parvovirus B19 enfeksiyonunun konjenital korneal opasitelere, kardiyak, hepatik ve nörolojik malformasyonlara neden olabileceği bildirilmiştir $[32,33]$.

Varisella enfeksiyonu yetişkinde nadir görülmesine rağmen, gebelikte geçirildiğinde ciddi morbidite ve mortalite (gebede varisella pnömonisi, düşük ya da ölü doğum, fetüsde konjenital varisella sendromu, yenidoğanda neonatal varisella) nedenidir [18]. Primer maternal enfeksiyon $\% 8$ oranında primer fetal enfeksiyona neden olur. Sekeller enfeksiyon anında fetüsün gebelik haftasına bağlıdır [8]. Sağlık Bakanlığı Kanıta Dayalı Tıp Rehberinde gebeliğin 12.-24. haftaları arasinda varisella embriyopatisi riskinin \% 2-3 olduğu, gebeliğin diğer dönemlerinde riskin çok azaldığ 1 , eğer bir kadın doğumdan 0-5 gün önce veya doğumdan sonraki 2 gün içinde varisella geçirirse fetüsün veya yenidoğanın yüksek düzeyde enfeksiyon riski olduğu, bu yenidoğanların yaklaşık \%17'sinin de klinik olarak enfekte olduğu ve ölüm oranının \%31'e kadar yükseldiği belirtilmektedir [19].

\section{Erken Tanı}

Gebenin teratojen bir enfeksiyonla karşılaştığ 1 düşünülüyorsa en kısa sürede, enfeksiyona duyarlı olup olmadığı araştırılmalıdır. Primer infeksiyonun serolojik yöntemlerle saptanabilmesi için serokonversiyonun (özgül IgG sonucunun negatiften pozitife değişmesi) gösterilmesi gerekir.

Rutin antenatal tarama sirasinda CMV IgM sonucunun pozitif olması ile primer CMV enfeksiyonundan şüphelenilmektedir [4]. Fetal CMV enfeksiyonunun prenatal tanılanmasi amniosenteze temellenmelidir [12, 15]. Amniosentez maternal enfeksiyonun geçirildiği tahmin edilen zamandan en az 7 hafta sonra ve gebeliğin 21. haftasından sonra yapılmalıdır. Fetal CMV enfeksiyonu tanılanmasını takiben fetüste anomali gelişip gelişmediğini belirlemek için 2-4 hafta aralıklarla düzenli ultrasonografi 
yapılmalıdır $[12,15]$. Bu uygulamaların öneri düzeyi II-2A (klinik önlem için iyi bir kanıt) olarak belirtilmiştir [12]. CMV enfeksiyonu durumunda yenidoğan enfeksiyonunu azaltmak için uygun fetal girişimin etkinliği kanıtlandığ 1 takdirde, 8-12. gebelik haftalarında tüm gebelere IgM ve IgG düzeyleri ile tarama yapılmalıdır [8].

Maternal toksoplazma enfeksiyon tanısı genellikle serolojiktir. Toksoplazmaya özgü IgG ve IgM anikorları ilk olarak serum örneği ile belirlenir $[18,19]$. Özel endikasyonlar varsa $2 \mathrm{kan}$, serebrospinal s1v1, amniyotik s1v1 incelemeleri yapılabilir. Doğumdan sonraki konjenital toksoplazmozis tanısı genellikle birkaç farklı serum örneğini gerektirir [19].

Gebeliğin ilk 16 haftası içinde rubellalı hasta ile yakın teması olan veya rubella benzeri hastalıklar gelişen gebelerde, IgG ve IgM antikor düzeyleri değerlendirilmelidir. Temas, ikinci ve üçüncü trimesterde gerçekleşirse ve ilk trimesterde rubella IgG pozitif saptanmışsa tetkiklerin devamına gerek yoktur [31].

Parvovirus B19 enfeksiyonunda maternal enfeksiyon tanısı genellikle IgM pozitifliği veya IgG serokonversiyonu ile konur [8, 19]. Gebelikte parvovirusla temas gerçekleşirse, duyarlılığın belirlenmesi için IgG testi yapılmalı ve seronegatifse 2-3 hafta sonra tekrarlanmalidır.

Spesifik IgM testi ile parvovirus enfeksiyonu doğrulanır ve abortus riski yüksek olan gebeler belirlenebilir [17]. Gebelikte enfeksiyon doğrulanırsa, sonraki 6-12 hafta süresinde ultrason incelemeleri ile fetüs hidrops belirtileri yönünden izlenmeli, hidrops meydana gelirse uzmana yönlendirilmelidir [4].

Eğer anne 24. haftadan önce varisella tanıs1 alırsa, hastalıktan sonra bir fetal anomali tetkiki düşünülebilir ve bazı durumlarda fetal enfeksiyon, amniyotik sıvının nükleik asit testi ile belirlenebilir. Varisella enfeksiyonunda temas zamanı tam bilinmeyen aşısız veya serokonversiyon gelişimi doğrulanmayan aş1lı gebelere, en kısa sürede varisella IgG testi yapılmalıdır. IgG negatif ise mümkün olduğunca erken (10 gün içinde) VZIg verilmelidir [18].

\section{Tedavi}

Sifilizde erken tanı ve tedavi önemlidir. Gebede sifiliz tanılandığında tedavi edilmelidir $[1,15,19]$. Sifiliz tedavisinde parenteral penisilin $G$ gebelik sırasında fetüse karşı etkinliği kanıtlanan, sifilizin tüm evrelerinde kullanımı tercih edilen tek tedavidir [19, 34, 35].
Günümüzde, gebelerde CMV enfeksiyonunun tedavisi yoktur. Seronegatif gebelere hiperimmün globülin (HIG) verilerek enfeksiyon önlenebilir [4]. 1950 den beri gebelikte immünglobulinler kullanılmakta olup HIG güvenliği ile ilgili toksisite gözlenmemiştir [13]. Ancak konjenital CMV enfeksiyonunun önlenmesi veya tedavisinde CMV özgül HIG kullanılmasını önermek için kanıtlar yetersizdir [13, 30]. Çok sayıda gözlemler gebelikte CMV ile enfekte kadınların ve fetüslerin tedavisinde HIG uygulamasının muhtemel etkinliğini desteklemektedir. Gebeliğinde primer CMV enfeksiyonu olan kadınlarda profilaktik HIG uygulananların $\% 16$ 'sında fetüs doğduğunda enfekte olmasına karşın HIG uygulanmayanların \%56'sında fetüsün doğduğunda enfekte olduğu belirlenmiștir. RKÇ sonuçları obstetrisyenler arasında gebelikte HIG kullanımına ilișkin fikir birliği olduğunu göstermektedir. Özellikle sonografide fetal etkilenme olduğunda 37. gebelik haftasında gebeliğin sonlandırılmasına alternatif olarak değerlendirilebilir [30].

Gebelikte akut toksoplazma enfeksiyonunun tedavisinde amaç parazitin fetüse geçmesini engellemek, eğer geçmişse enfekte fetüste doku hasarını önlemektir $[15,18]$. Gebelikte tedavide spiramisin kullanılmaktadır. Bu enfeksiyonun bulaşma riskini azaltır. Eğer fetüs enfekte ise etkin değildir. Fakat fetal enfeksiyon saptandığında gebelik devam edecekse pirimetamin ve sülfadiyazin önerilebilir [18]. Rubella virüs enfeksiyonlarından korunmada immunglobulin veya HIG etkinliği pratik olarak ortaya konulamamıştır. Rubella virüsüne özgül antiviral tedavi bulunmamaktadır [8].

Sağlık Bakanlığı Kanıta Dayalı Tıp Rehberinde doğum esnasında genital herpesin aktivitesini azaltmak amaciyla asiklovir (beș gün boyunca günde $5 \mathrm{kez} 200 \mathrm{mg}$ ) özellikle ilk enfeksiyonda kullanılabildiği, tekrarlayan enfeksiyonlarda da annenin semptomların hafifletmek ve fetüse potansiyel koruma sağlamak için kullanılabildiği belirtilmektedir [19]. HSV enfeksiyonu tedavisinde asiklovir ve diğer HSV ye karşı etkili antiviraller plasentayı geçmekte ancak fetüste birikim yapmadığından gebelikte kullanımı güvenlidir (kategori B) [8]. Hollier ve Wendel'in (2008) yaptıkları Cochrane sistematik çalışmasında HSV'de antiviral profilaksinin neonatal herpes insidansinı azaltt1ğını belirlemede kanıtların yetersiz olduğu, antenatal antiviral profilaksi doğumda viral yayılımı ve nüksü, genital herpeste sezaryen gereksinimini azalttığı, profilaksinin neonatal güvenliği ile ilgili sınırlı bilgi bulunduğu saptanmış ve profilaksi uygulanmasını isteyen kadınla profilaksi riskleri, yararları ve alternatiflerinin tartışılması gerektiği belirtilmiştir [36]. 
Parvovirus B19 enfeksiyonu tedavisinde terapötik girișimleri değerlendiren bir çalıșmaya rastlanmamıştır. Bilinen bir antiviral tedavi yoktur [8]. Varisella tedavisinde asiklovir ve valasiklovir gibi antiviral ilaçlar maruziyet sonrası profilaksi olarak kullanılabileceğini belirten kaynaklar bulunmakla birlikte erken gebelik döneminde tedavinin fetüs için yararı tartışmalıdır [10]. Antiviral tedavi geç gebelik dönemindeki gebede solunum sistemi şikayetleri varsa endikedir. Varisella gelișen gebelerde asiklovir döküntülerin başlamasından 24 saat içinde verilmeli ve duyarlı bireylerle temastan kaçınılmalıdır [8, 18]. Sağlık Bakanlığı Kanıta Dayalı Tıp Rehberinde eğer seronegatif bir annenin, varisella ile 24.gebelik haftasından önce bir teması olursa, temastan sonraki 7-9 gün için asiklovir kullanımının (7 gün boyunca günlük $800 \mathrm{mg}$ ) düşünülmesi gerektiği belirtilmektedir [19].

\section{Gebeliğin devamı / sonlandırılması}

Akut maternal CMV enfeksiyonu gebeliğin sonlandırılması için endike değildir. Fetüste enfeksiyon saptandığ 1 durumlarda detaylı ultrasonografi yapılmalı, riskler aileye ayrıntılı olarak anlatılmalı, karar aileye bırakılmalıdır [15]. CMV enfeksiyonunda ultrasonografide ciddi şekilde etkilendiği tespit edilen fetüslerde ciddi sekel olasılığı yüksektir ve gebeliğin sonland1r1lmas1 önerilebilir [8]. Maternal toksoplazma enfeksiyonu söz konusu olduğunda riskler, gebeliğin sonlandırılma olasılığı ve yönetimiyle ilgili konularda gebeye danışmanlık verilmeli, özellikle fetüsün kesin pozitif olduğu ve enfeksiyonun ilk trimesterde meydana geldiği olgularda gebeliğin sonlandırılması önerilebilir $[8,18]$.

Gebeliğin ilk 12 haftasında rubella enfeksiyonu geçiren gebelerde gebeliğin sonlandırılma endikasyonu vardır. Gebeliğin 16. haftasından sonra geçirilen enfeksiyonda fetüsün ciddi düzeyde zarar görme riski düşüktür. Gebeliğin 12-16 haftaları arasında ise prenatal tanı uygulanması ve fetüste enfeksiyon saptanması durumunda gebeliğin sonlandırılması seçeneği gebelere sunulmalidir $[15,18]$. Varisella enfeksiyonunda gebeliğin sonlandırılma endikasyonu yoktur. Gebe enfeksiyonu geçiren biriyle temas ederse maternal immünizasyon değerlendirilmelidir [15].

\section{Doğum şekli}

HPV 2 enfeksiyonunda gebede aktif lezyonlar varsa özellikle doğum zamanında ilk kez genital herpes lezyonlarına rastlanırsa sezaryenle doğum önerilmektedir [1, 8,15]. Genital herpes enfeksiyonu olan ancak doğum anında aktif genital lezyonları olmayan kadınlarda sezaryenle doğum endikasyonu yoktur $[8,15]$.

\section{SONUÇ}

Teratojen enfeksiyonlar fetüste ileri düzeylerde sekellere neden olduğundan bu enfeksiyonların önlenmesinde ve yönetiminde tüm sağlık çalışanlarının kanıt temelli yaklaşımlarda bulunması, kanıta dayalı uygulamaları rehber alması önemli hatta gereklidir. Fetüste/yenidoğanda oluşabilecek sekellerin önlenebilmesi için prekonsepsiyonel dönemden başlayarak doğurgan çağdaki kadınların bu enfeksiyonlara yönelik değerlendirilmesi, gebelik planlayan kadın ve eşinin prekonsepsiyonel bakım alması, bu süreçte özellikle bazı enfeksiyonlara yönelik immüniteyi belirleyecek şekilde rutin tarama testleri yapılmas1, enfeksiyonlardan korunmas1, enfeksiyon gelişmesi durumunda erken tanı ve tedavisinin sağlanması, gebeliğin yönetimi kanıt temelli güncel uygulamalar doğrultusunda gerçekleştirilmelidir.

\section{KAYNAKLAR}

1. Taşkın L. Doğum ve Kadın Sağlı̆̆ Hemşireliği. Özyurt Matbaacılık, Ankara, 2016.

2. Kızılkaya Beji N. (Ed). Kadın Sağlı̆̆l ve Hastalıkları. Nobel Tip Kitabevleri, Istanbul, 2015.

3. Keskin DD, Keskin S. Ilk trimester gebelerde Toksoplazma, Rubella, CMV, HBV, AntiHBs, HCV, HIV Seroprevelansları. Selçuk Tip Derg 2013; 29(3):123-126.

4. $\quad$ Özerol IH. Gebe kadınlarda viral infeksiyonlar. İn̈nü Üniversitesi Tip Fakültesi Dergisi 2008; 15(4):291-298.

5. Çopur Ciçek A, Duygu F, Inakçı IH, Boyar N, Boyar IH. Investigation of Toxoplasma gondii antibodies with ELISA among women of childbearing age in Şanlurfa province: A three years evaluation. Journal of Clinical and Experimental Investigations 2012; 3(1):61-65.

6. Iraz M, Gültepe B, Ceylan A, Doymaz MZ. Doğurganlık çağındaki kadınlarda toksoplazma seroprevalansı. Abant Med J 2015; 4(1):11-14.

7. Shahrook S, Mori R, Ochirbat T, Gomi H. Strategies of testing for syphilis during pregnancy. Cochrane Database Syst Rev 10:2014, CD010385.

8. Gezer A. (Çev Ed). Maternal-Fetal Tıp Kanıta Dayalı Klinik Kllavuzlar. Berghella V. (Ed). Maternal-Fetal Evidence Based Guidelines. Istanbul:Istanbul Medikal Yayıncllık. 2009.

9. Malm G, Engman ML. Congenital cytomegalovirus infections. Semin Fetal Neonatal Med 2007;12:154-159.

10. KH Ahn, Park YJ, Hong SC, Lee EH, Lee JS, Oh MJ \& Kim HJ. Congenital varicella syndrome: A systematic review. Journal of Obstetrics and Gynaecology 2016; Early Online: 1-4.

11. de Jong EP, de Haan TR, Kroes AC, Beersma MF, Oepkes D. Parvovirus $B 19$ infection in pregnancy. J Clin Virol 2006; 36:1-7.

12. SOGC Clinical Practice Guideline. Cytomegalovirus Infection in Pregnancy APRIL JOGC AVRIL 2010; No. 240. 
13. Adler SP. Screening for Cytomegalovirus during Pregnancy. Infectious Diseases in Obstetrics and Gynecology 2011;1-9.

14. McCarthy FP, Giles ML, Rowlands S, Purcell KJ, Jones $C A$. Antenatal interventions for preventing the transmission of cytomegalovirus (CMV) from the mother to fetus during pregnancy and adverse outcomes in the congenitally infected infant. Cochrane Database Syst Rev 3:2011, CD008371.

15. Şirin A. (Ed). Kadın Sağlığı. Bedray Basın Yayıncılık, Istanbul, 2008

16. Tekin A, Deveci Ö, Yula E. Mardin'de doğurganlık çağındaki kadınlarda toksoplazma ve rubella antikor seroprevalanst. J Clin Exp Invest 2010;1(2): 81-85.

17. el-Sayed ZM, Goda H. Relevance of parvovirus B19, herpes simplex virus 2, and cytomegalovirus virologic markers in maternal serum for diagnosis of unexplained recurrent abortions. Arch Pathol Lab Med 2007; 131:956-960.

18. Soğukpınar N. (Çev. Ed). Gebelikte Tıbbi Problemler Ebeler İçin El Kitabı. Robson SE, Waugh J. (Ed). Medical Disorders in Pregnancy A Manuel for Midwives. Ankara: Nobel Akademik Yayıncılık Eğitim Danışmanlık Tic. LTD. ŞTI. 2016.

19. Kanita Dayalt Tip Rehberi. www.rehber.saglik.gov.tr. Erişim tarihi:10/03/2017.

20. Gollub EL, Leroy V, Gilbert R, Chêne G, Wallon M, the European Toxoprevention Study Group (EUROTOXO). Effectiveness of health education on Toxoplasma-related knowledge, behaviour, and risk of seroconversion in pregnancy. European Journal of Obstetric \& Gynecology and Reproductive Biology 2008; 136:137-145.

21. Di Mario S, Basevi V, Gagliotti C, Spettoli D, Gori $G$, D'Amico R, Magrini N. Prenatal education for congenital toxoplasmosis. Cochrane Database Syst Rev 10:2015, CD006171.

22. American Academy of Pediatrics Committee on Infectious Diseases. Prevention of varicella: recommendations for use of varicella vaccines in children, including a recommendation for a routine 2-dose varicella immunization schedule. Pediatrics 2007;120:221-231.

23. CDC Progress toward control of rubella and prevention of congenital rubella syndrome-worldwide. 2009. MMWR Morb Mortal Wkly Rep 2010; 59: 1307-1310

24. Riley LE. Rubella in pregnancy. June 7, 2010. www. uptodate.com
25. CDC General recommendations on immunization: recommendations of the Advisory Committee on Immunization Practices (ACIP). MMWR 2011; 60 (2):26-27.

26. United States Preventive Services Task Force. Final Recommendation Statement Syphilis Infection in Pregnancy: Screening, May 2009. www.uspreventiveservicestaskforce.org

27. National Institute for Health and Clinical Excellence [NICE] clinical guideline 62. Antenatal care. 2010. /www.nice.org.uk/guidance/qs22/documents/antenatal-care 5

28. Hawkes S, Matin N, Broutet N, Low N. Effectiveness of interventions to improve screening for syphilis in pregnancy: a systematic review and meta-analysis. Lancet Infectious Diseases 2011;11(9):684-691.

29. Bod'eus M, Kabamba-Mukadi B, Zech F, Hubinont C, Bernard P, Goubau P. Human cytomegalovirus in uterotransmission: follow-up of 524 maternal seroconversions. Journal of Clinical Virology 2010; 47(2):201-202.

30. Adler SP, Nigro G. Findings and conclusions from CMV hyperimmune globulin treatment trials. Journal of Clinical Virology 46S 2009; 54-57.

31. Best JM. Rubella. Semin Fetal Neonatal Med 2007; 12:182-192.

32. Bonvicini F, Puccetti C, Salfi NC, Guerra B, Gallinelle $G$, Rizzo N, Zerbini M. Gestational and fetal outcomes in B19 maternal infection: a problem of diagnosis. J Clin Microbiol 2011; 49:3514-3518.

33. Schulert GS, Walsh WF, Weitkamp JH. Polymicrogyria and Congenital Parvovirus B19 Infection. Am J Perinatol Rep 2011; 1(2):105-110.

34. Chandrasekar PH. Syphilis Treatment \& Management: Approach Considerations, Antibiotic Therapy, Surgical Care. Updated: Feb 16, 2016.

35. Sexually Transmitted Diseases Treatment Guidelines 2015. Centers for Disease Control and Prevention. Morbidity and Mortality Weekly Report (MMWR) Recommendations and Reports 2015; 64(3).

36. Hollier LM, Wendel GD. Third trimester antiviral prophylaxis for preventing maternal genital herpes simplex virus (HSV) recurrences and neonatal infection. Cochrane Database Syst Rev 1:2008, CD004946. 